IZA DP No. 9805

Born Entrepreneur?

Adolescents' Personality Characteristics and

Self-Employment in Adulthood

Jutta Viinikainen

Mirka Hintsanen

Guido Heineck

Petri Böckerman

Olli Raitakari

Jaakko Pehkonen

March 2016 


\title{
Born Entrepreneur? \\ Adolescents' Personality Characteristics and Self-Employment in Adulthood
}

\author{
Jutta Viinikainen \\ Jyväskylä University \\ School of Business and Economics \\ Guido Heineck \\ University of Bamberg and IZA \\ Petri Böckerman \\ Turku School of Economics, \\ Labour Institute for Economic Research \\ and IZA
}

\author{
Mirka Hintsanen \\ University of Oulu
}

Olli Raitakari

CAPC, University of Turku

and Turku University Hospital

Jaakko Pehkonen

Jyväskylä University

School of Business and Economics

\section{Discussion Paper No. 9805}

March 2016

\author{
IZA \\ P.O. Box 7240 \\ 53072 Bonn \\ Germany \\ Phone: +49-228-3894-0 \\ Fax: +49-228-3894-180 \\ E-mail: iza@iza.org
}

\begin{abstract}
Any opinions expressed here are those of the author(s) and not those of IZA. Research published in this series may include views on policy, but the institute itself takes no institutional policy positions. The IZA research network is committed to the IZA Guiding Principles of Research Integrity.

The Institute for the Study of Labor (IZA) in Bonn is a local and virtual international research center and a place of communication between science, politics and business. IZA is an independent nonprofit organization supported by Deutsche Post Foundation. The center is associated with the University of Bonn and offers a stimulating research environment through its international network, workshops and conferences, data service, project support, research visits and doctoral program. IZA engages in (i) original and internationally competitive research in all fields of labor economics, (ii) development of policy concepts, and (iii) dissemination of research results and concepts to the interested public.
\end{abstract}

IZA Discussion Papers often represent preliminary work and are circulated to encourage discussion. Citation of such a paper should account for its provisional character. A revised version may be available directly from the author. 


\section{ABSTRACT \\ Born Entrepreneur? Adolescents' Personality Characteristics and Self-Employment in Adulthood}

Is there an entrepreneurial personality and does it appear early in life? We provide a new answer on this question by using the so-called Type A behavior traits (Aggression, Leadership, Responsibility, and Eagerness-Energy), measured in childhood and adolescence, and examining their relationship to self-employment propensity in adulthood. Using data from the Young Finns Study linked to the Finnish Longitudinal EmployerEmployee Data and the Longitudinal Population Census of Statistics, our results show that the early-life Leadership-dimension is significantly associated with a higher likelihood 1) of becoming self-employed later in life and 2) of being more successful as an entrepreneur, as approximated by sales. Our results also reinforce the prior evidence on the intergenerational transmission of entrepreneurship.

JEL Classification: L26

Keywords: Type A behavior, personality, self-employment, entrepreneurship, intergenerational transmission of entrepreneurship

Corresponding author:

Guido Heineck

University of Bamberg

Department of Economics

Feldkirchenstr. 21

D-96045 Bamberg

Germany

E-mail: guido.heineck@uni-bamberg.de 


\section{Introduction}

Entrepreneurs exploit new technological breakthroughs (Holmes and Schmitz, 1990), commercialize innovations (Braunerhjelm et al. 2010), drive technological change (Schumpeter 1934) and therefore promote economic growth. However, not all entrepreneurship can be characterized by innovation and exploitation of new profitable opportunities (Baumol 1990). Some entrepreneurs are passive followers or overly optimistic gamblers or individuals for whom entrepreneurship may be an alternative to uncertain labor market prospects and unemployment (Santarelli and Vivarelli 2007). In such a case, the business success might be weak, and entrepreneurship would not have the desirable positive effects on economic growth. It is therefore crucial to understand who becomes a successful entrepreneur in order to develop adequate policies that support individuals who pursue successful entrepreneurial careers.

Entrepreneurship requires financial, social and human capital which constitutes the stock of entrepreneurial capital (Blumberg and Pfann 2015). Because individuals differ in their stock of entrepreneurial capital, the probability to become and reach success as an entrepreneur varies between individuals. The differences in entrepreneurial capital may stem from various sources (Blumberg and Pfann 2015), such as personality characteristics, which are considered as an essential element of human capital (Mueller and Plug 2006). As a part of human capital, personality characteristics may affect an individual's productivity and, therefore, entrepreneurial ability. Personality characteristics may further affect individuals' entrepreneurial intentions and success through motivation. As Barrick, Mount and Li (2013) suggest, differences in personality drive individuals to pursue higher order implicit goals (communion, status, autonomy and achievement) to a greater or lesser extent. Because the possibility to achieve these goals may vary between entrepreneurs and salary earners, the attractiveness of an entrepreneurial career may vary between individuals.

Previous literature in psychology and economics shows that personality characteristics and risk attitudes are related to individuals' propensity of becoming and experiencing success as an entrepreneur (for meta-analyses see Brandstätter 2011; Frese and Gielnik 2014; Rauch and Frese 2007; Zhao and Seibert 2006; for the relationship between risk attitudes and entrepreneurship see Caliendo et al. 2009, 2010). This may be true because personality characteristics, as an additional aspect of entrepreneurial capital, can be seen as skills that contribute to the entrepreneurial process or, as aforementioned, as characteristics that influence the attractiveness of an entrepreneurial career for an individual by establishing possibilities to aspire for higher order goals (Barrick et al. 2013).

In addition to personality characteristics another potential source of entrepreneurial capital is family background. Particularly the role of self-employed parents on entrepreneurial capital may be substantial because in addition to providing financial assets or an opportunity to take over the family business, successful self-employed parents may transfer self-employment specific skills to their 
offspring (Lindquist et al. 2015). Consistent with this perspective, earlier empirical literature has identified parental self-employment as a predictor for self-employment of their offspring (see e.g., Colombier and Masclet 2008; Lindquist et al. 2015).

Given this evidence, it is interesting to examine whether such a personality-based propensity towards entrepreneurship can be identified early in life, i.e., before labor market entry, and whether intergenerational aspects, such as parental preferences for entrepreneurship, might establish norms to which children adhere. We thus add to the literature by examining the so-called Type A behavioral characteristics - Aggression, Leadership, Responsibility and Eagerness-Energy - psychological constructs that have not been explored before in this context, and how these characteristics are related to the entrepreneurial process. Another contribution is that we explore personality characteristics that were measured in childhood and adolescence and exploit a longitudinal research design to examine whether pre-market characteristics are related to the propensity of becoming and succeeding as an entrepreneur over a 20-year period.

\section{Personality characteristics and entrepreneurship}

The link between individuals' characteristics and their entrepreneurial propensity can be framed within a concept from organizational psychology, the so-called RIASEC vocational personality model as introduced by Holland (1985). Out of the set of six work-related characteristics, ${ }^{1}$ it is the E-type, i.e., the "Persuaders (Enterprising)"-type, which is the most relevant for our context. According to this concept, an "individual is considered entrepreneurial when he or she displays entrepreneurial competence along with a preference for enterprising activities. [...] Although not all E-types become successful entrepreneurs, [...] most entrepreneurs display E-typical interests, abilities, and behaviors.” (Schmitt-Rodermund 2004: 499).

In line with this, prior literature has characterized successful entrepreneurs as individuals who detect and exploit opportunities; make rapid decisions under uncertainty; and are hard-working, goal striving and willing to take risks (Brandstätter 2011; Rauch and Frese 2007). Entrepreneurs have also been characterized as generalists or "jack-of-all-trades” who must be able to perform a wide range of job tasks to succeed (Lazear 2004). Previous research has further identified several personality characteristics that are related to the probability of becoming and finding success as an entrepreneur. For example, in a meta-analytic study, Rauch and Frese (2007) identified the following characteristics as associated with both business creation and success: need for achievement, innovativeness,

\footnotetext{
${ }^{1}$ The five other types are: R - Doers (Realistic), I - Thinkers (Investigative), A - Creators (Artistic), S Helpers (Social), and C - Organizers (Conventional).
} 
proactive personality, generalized self-efficacy, stress tolerance, need for autonomy and internal locus of control. Additionally, Brandstätter (2011) linked similar characteristics, along with achievement motivation, to entrepreneurs and entrepreneurial success. In the context of the Big Five personality traits, Brandstätter (2011) found that higher Conscientiousness, Openness, Extraversion, and lower Neuroticism distinguished entrepreneurs from managers, and these traits also predicted entrepreneurial success. ${ }^{2}$ Zhao and Seibert (2006) arrived at similar results with the distinction that they found no differences in Extraversion between entrepreneurs and managers.

In addition to the Five Factor Model traits or other personality-related constructs such as self-efficacy or locus of control, Type A behavior is an interesting construct because many of the characteristics frequently associated with successful entrepreneurs are very similar to behaviors that are part of Type A behavioral pattern. Individuals who exhibit a Type A behavioral pattern are characterized as harddriving, competitive, achievement-oriented, impatient, and work involved (Lee et al. 1988). As the developers of the Type A and Type B personality theory explain, Type A behavior characterizes individuals who are "aggressively involved in a chronic, incessant struggle to achieve more and more in less and less time” (Friedman and Rosenman 1974: 84). Certain dimensions of Type A behavior, such as high need for achievement, high energy levels, high job involvement, and ability to handle multiple projects simultaneously, may produce higher entrepreneurial performance. On the other hand, Type A behavior has also been related to hostility, anger, and emotional instability, which can lead to interpersonal conflicts and frustration if business success is weak (Morrison 1997).

The empirical results concerning Type A behavior and job performance have been mixed. While Type A behavior has been related, for example, to higher research productivity among university faculty (Matthews et al. 1980; Taylor et al. 1984) it seems not to improve performance for sales professionals (Matteson et al. 1984), college teachers (Jamal and Baba 2001) or white-collar rank-and-file employees (Jamal 1985). According to Lee et al. (1988), the discrepancy may result because Type A individuals perform better in jobs with high task variety. Because Type A behavior has also been linked to the need to achieve control over tasks (Burnam et al. 1975), entrepreneurship may provide an attractive opportunity to Type A individuals who seek high task variety with a great control over one's work.

Thus far, Type A behavior (or its dimensions) has been used only minimally in entrepreneurship research. The evidence from these studies suggests that Type A behavior (or its dimensions) is positively related to the likelihood of being an entrepreneur (Babb and Babb 1992; Begley and Boyd 1987; Corzine and Hood 1998) and with growth (Begley amd Boyd 1987), but not necessarily with

\footnotetext{
${ }^{2}$ De Fruyt and Mervielde (1997) show, that - with the exception of openness to experience - all other Five Factor traits relate to Holland's E-type.
} 
entrepreneurial profits (Begley amd Boyd 1987). Our paper contributes to earlier US-based literature by analyzing rich longitudinal data from the Finnish setting.

In addition, as mentioned above, we use pre-market information on individuals' Type A behavioral traits so that we can also examine whether trait patterns measured earlier in life are predictive for individuals' future entrepreneurship propensity. So far, and to the best of our knowledge, there are also only very few studies that address this particular aspect. Drawing from the British NCDS data, Blanchflower and Oswald (1998), for example, use assessments of hostility and acceptance anxiety that were conducted in the individual's childhood and relate these to the probability of running and owning a business at age 33. Their findings suggest that persons who were anxious for acceptance in their childhood are less likely to be self-employed in adulthood. They further tried "many other psychological variables” (Blanchflower and Oswald 1998: 38), but conclude that based on the variables available to them, psychological traits would not play a key role in determining who becomes an entrepreneur.

In terms of career aspirations, Schmitt-Rodermund (2004) uses data on school students from East Germany ranging ages 14 to 17 years and shows that adolescents' entrepreneurial personality is related to early entrepreneurial competence and career prospects, but not directly to entrepreneurial interests. In addition, the results further show that students with self-employed parents (or other family members) have a higher willingness to pursue an entrepreneurial career. This fits with the overall evidence of an intergenerational transmission mechanism, i.e., that children from selfemployed individuals are more likely to enter self-employment themselves (see, e.g., Sørensen 2007; Colombier and Masclet 2008 or Andersson and Hammarstedt 2010). As our data also provides information on parental entrepreneurship, we are able to control for this mechanism in our analyses. Interestingly, Chlosta et al. (2012) argue that parental role models might also be moderated by personality.

\section{Data and methodological issues}

We examine the relationship between personality and entrepreneurship using longitudinal data that combines three data sources. The first source is the Cardiovascular Young Finns Study (YFS), a longitudinal survey launched in 1980. The YFS started with a total of 3,596 participants from six age cohorts (aged 3, 6, 9, 12, 15, and 18 in 1980), who were randomly chosen from five Finnish university regions. Since 1980, there have been several follow-up studies, most recently in 2011/12. For our analyses, we dropped observations from individuals who had never been employed or self-employed $(\mathrm{N}=51)$ and observations with missing information in explanatory variables. The final estimation sample we use in the baseline OLS estimations is $\mathrm{N}=1,981$. Type A behavior was measured in the 
YFS in 1983 and 1986 among the four oldest age cohorts using the Hunter-Wolf A-B Rating Scale (Wolf et al. 1982).

The Hunter-Wolf Rating scale consists of the four components that were measured using the following items (Jokela and Keltikangas-Järvinen 2009; Wolf et al. 1982):

a) Aggression: It takes very little to get me angry, I tend to get into fights easily, I often interrupt when someone else is talking, I find it difficult to wait, I talk loudly, I like to argue with others, I lose my temper easily (Cronbach’s alpha 0.68).

b) Eagerness-energy: I am always in a hurry, I walk with a fast pace, I think time often passes quickly, I talk fast, I eat fast, I think about many things at the same time, I drink fast (Cronbach's alpha 0.56).

c) Leadership: I always take charge of things, my peers always choose me to be a leader in various activities, I always want to win, I like to tell others what to do, I have many hobbies, I am interested in many things (Cronbach’s alpha 0.65).

d) Responsibility (3 items): I am hard-driving, It bothers me if I am late, I take things seriously (Cronbach’s alpha 0.64).

Responses to the items were given on a Likert-type 7 -point scale $(1=$ totally disagree, $7=$ totally agree). In our analyses, we use standardized average scores for each dimension.

The YFS data are linked to the Finnish Longitudinal Employer-Employee Data (FLEED) of Statistics Finland (SF) using unique personal identifiers. The FLEED contains comprehensive administrative register information on individuals' entrepreneurship spells and entrepreneurial success such as firm's annual sales for the period 1990-2010. The third data source is register information on parental background, based on the Longitudinal Population Census of Statistics (LPC), which was also linked to YFS/FLEED using unique personal identifiers. The LPC, which covers the entire Finnish population, provides information on parents' education, their total taxable annual income, and their self-employment status in 1980.

The linked data allow a longitudinal research design enabling us to address two potential problems that may influence the results. The first is reverse causality, which emerges if entrepreneurship affects personality characteristics. Potential reverse causality makes the interpretation of the results challenging in a cross-sectional setting because the direction of causality is difficult to identify. In the 1986, YFS personality characteristics were obtained from participants between the ages of 12 and 24, 
before the majority of participants had any significant labor market experience. ${ }^{3}$ This mitigates the possibility that labor market experiences would have affected personality. ${ }^{4}$

The second potential problem is measurement error, which may stem from three sources. First, the time lag between the measurement of personality characteristics and labor market outcomes may cause measurement error problems if personality characteristics change over time. To account for that, we use Type A personality characteristics obtained in 1983 as instruments for those measured in 1986 in additional analyses. The instrumental variable (IV) approach mitigates the classical measurement error bias and also the potential omitted variable bias in a specific case where the omitted variable is correlated only with the 1986 measure. The second potential source of measurement error stems from self-reported data. Self-assessed labor market information would be problematic if personality affects the way individuals assess their performance in the labor market (Hamermesh 2004). An advantage of our linked data is that the labor market outcomes are taken directly from tax and other administrative registers, which eliminates the potential measurement problem. Finally, as Haider and Solon (2006) and Böhlmark and Lindquist (2006) noted, cross-sectional measures are rather inaccurate proxies for individual's long-term labor market performance. In the case of entrepreneurship this may be particularly problematic because the relationship between personality and entrepreneurial performance may depend, for example, on macroeconomic conditions (Hmieleski and Baron 2008) or the phase of firm development (Vecchio 2003). Hmieleski and Baron (2008), for example, found that high self-efficacy has a positive impact on entrepreneurial performance in dynamic environments, but had only a weak effect on performance in stable economic environments. According to Vecchio (2003), overconfidence may be critical at the start-up phase, while it may later cause difficulties for the firm's viability. We implicitly address these potential problems that may occur when using crosssectional data because we use aggregated long-term labor market information over a 20-year period (1990-2010).

\section{Results}

\subsection{Descriptive findings}

Table 1 contains descriptive statistics for the main variables. Over the period 1990-2010, 18\% of participants had been entrepreneurs at least once. Males are somewhat more likely to have ever been

\footnotetext{
${ }^{3}$ For the 1983 wave, average age is 15.9 years; for 1986, it is 17.3 years. In both waves, less than a quarter of survey participations had already entered the labor market indicated by positive labor market earnings. By using this definition the group of labor market entrants includes also individuals who have had only minor labor market experience based on for example summer jobs.

${ }^{4}$ In additional analyses, we dropped these observations from our sample and rerun the models. The overall results did not change.
} 
self-employed than females (22\% compared to $15 \%$ ). The average number of entrepreneurship spells is approximately 1.3 for both males and females, but the average duration of males' spells is somewhat longer than the average duration of females' spells (7.4 years compared to 6.1 years, with 6.8 years being the overall average duration). Accordingly, males are also more likely to have been self-employed for more than five successive years.

The Type A behavior traits also differ by gender. According to the measures taken in 1986, which were recorded when the participants were, on average, approximately 17 years old, females have somewhat higher scores in Aggression than males, score somewhat lower in the Leadership dimension, have higher scores in Responsibility, and score slightly higher in Eagerness-Energy than males. The gender differences are significant at the 1\% level except for Eagerness-Energy, in which case the gender difference is insignificant at conventional levels.

- Table 1 about here -

Table 2 documents the personality measures and socio-demographic characteristics by selfemployment status. Compared to the gender differentials in Type A behavior traits shown above, there is less evidence for personality differentials by entrepreneurship status. Out of the four dimensions, Leadership is the only trait for which there is a statistically significant difference as individuals, who have been entrepreneurs at least once between 1990 and 2010, have, on average, higher scores in Leadership.

As could have been expected, entrepreneurship is more prevalent among males than females and compared to those who have never been entrepreneurs, individuals with entrepreneurial experience have lower education. The share of marital years between 1990-2010, however, is larger compared to non-entrepreneurs, possibly due to differences in the age profiles of the two groups. Having an entrepreneurial family background also increases the probability of being an entrepreneur. The probability of having an entrepreneurial background increases with age and compared to other geographical regions, self-employment is more prevalent in the Turku area, a region in southwest Finland, which corresponds to aggregate statistics (Yrittäjyyskatsaus 2012: 135, Figure 49)

- Table 2 about here -

Correlations between Type A behavior characteristics and entrepreneurial success, that is, for individuals who have at least once been self-employed, are presented in Table 3. There is a significant positive correlation between number of self-employment spells, annual sales and Leadership, as well as between Responsibility and average duration and number of self-employment spells. The raw correlations are otherwise statistically insignificant.

- Table 3 about here - 


\subsection{Regression analyses}

The baseline OLS estimates (Table 4), which condition on a range of control variables, ${ }^{5}$ reinforce the descriptive findings and confirm the association between the Leadership dimension of the Type A behavioral traits and the likelihood of being an entrepreneur. According to these results, a one standard deviation increase in Leadership is positively related to the probability of ever having been an entrepreneur (Column 1), with an increase of four percentage points. We also find increases in the share of entrepreneurial years ${ }^{6}$ (Column 2) by 0.016 points and an increase in the predicted probability of being an entrepreneur for at least five successive years by almost three percentage points. ${ }^{7}$ In further, unreported analyses by gender, we find that the positive connection between Leadership and entrepreneurial outcomes applies to both women and men and that the gender differences in the point estimates are statistically insignificant.

- Table 4 about here -

Apart from the findings for the Type A traits, our results furthermore reinforce prior research on intergenerational correlation patterns in self-employment. Having a self-employed parent is positively related to all three outcomes we observe, i.e., to individuals' self-employment propensity, the share of self-employment years and whether individuals have had at least 5 successive years in selfemployment. $^{8}$

As outlined above, we account for possible measurement-error issues in the personality traits by using measures surveyed in 1983 as instruments for the 1986 scores. Table 5 reports the estimates of the IV models. Although the sample size in the IV-model is reduced by a third, the results are consistent overall with the OLS results in Table 4. The OLS point estimates are included in the 95\% confidence interval of the IV estimates. The results again suggest that higher Leadership is related to a higher entrepreneurship propensity, a higher share of entrepreneurial years, and to an increase in the likelihood of being an entrepreneur for at least five successive years. The point estimates also increase in size, implying associations that are roughly twice as large as the OLS estimates. Interestingly, though, the IV estimates further show that Eagerness-Energy is negatively and Aggression positively related to individuals' share of self-employment years. As the coefficients are statistically significant only at the $10 \%$ level, this evidence is, however, not particularly strong.

\footnotetext{
${ }^{5}$ Although we provide the estimates for the covariates, we do not discuss the findings in detail to save space.

${ }^{6}$ Defined as the number of years spent in self-employment relative to the total number of years in the time period 1990-2010.

${ }^{7}$ We also estimated the models in Columns 1 and 3 using logit models, calculated average marginal effects and got similar results. Full results are available upon request.

${ }^{8}$ We have run additional regressions without this covariate, to check whether the Type-A traits would substantially change as this would indicate that the intergenerational transmission operates via the personality similarities between parents and children. The results are, however, almost identical.
} 
We use three measures as indicators of entrepreneurial success: average duration of self-employment spell, number of self-employment spells, ${ }^{9}$ and sales. To this end, we condition on having being selfemployed at least once in our time period, which causes a substantial decrease in sample size, most notably for sales. Thus, the interpretation of these estimates has to be done with caution. However, the results in Table 6 indicate that Leadership, which was related to a higher probability of being an entrepreneur, is also positively related to the number of self-employment spells and higher sales. In addition, Responsibility is now also positively associated with the number of self-employment spells, but beyond that, the point estimates between the other Type A behavior traits and our entrepreneurial success measures are not significantly different from zero.

- Table 6 about here -

In sum, the results concerning Leadership and entrepreneurial interests (Table 4 and 5) are in line with Babb and Babb (1992), Begley and Boyd (1987), and Corzine and Hood (1998), who all found a positive connection between Type A behavior in adulthood and the probability of being an entrepreneur. Our results on entrepreneurial success, approximated by sales (Table 6), are also consistent with Begley and Boyd (1987), who found a positive relationship between Type A behavior and growth. It therefore seems that an entrepreneurial career attracts high Leadership individuals who are able to generate growth; whether they are able to make their business successful in the long run is not clear. According to Begley and Boyd (1987), higher Type A tendencies were related to lower profit trends. Also our result, that Leadership is positively related to the number of self-employment spells, may be an indicator of business failures, which would support the interpretation, that in the long run, high Leadership may not be enough for business viability. As Vecchio (2003) suggested, the critical characteristics for entrepreneurial success may depend on the stage of the firm's development, and this may also be the case for Leadership.

\section{Conclusions}

Research in economics on the entrepreneurial personality has grown in recent years, partly because of the availability of psychometric data in large-scale surveys. Whereas much of this research employs constructs, such as individuals' risk attitudes or the Five Factor Model traits, we add to the literature by exploring an under-researched concept, the so-called Type A behavior traits comprising Aggression, Leadership, Responsibility, and Eagerness-Energy. Our second contribution is our use of

\footnotetext{
${ }^{9}$ It is not particularly clear whether this is a convincing measure for entrepreneurial success as it may also indicate several business failures.
} 
linked data from three survey and register based sources, covering the time period between the mid1980s and 2010, which allowed us to examine whether it is adolescents' personality that is predictive for becoming and succeeding as an entrepreneur in adulthood. To this point, this life course perspective has been addressed only very sparingly in the literature on entrepreneurship.

Our results from OLS and IV regressions indicate that from the four mentioned traits, it is only adolescents' Leadership dimension that is relevant for their entrepreneurial propensity and success, approximated by sales, in their adulthood. This is plausible as the Leadership construct aims at measuring, for example, the individual's desire to win or to take charge. These are qualities that are quite likely needed to succeed as entrepreneurs. Reinforcing prior evidence on the intergenerational transmission of entrepreneurship, we further find that having self-employed parents increases the likelihood of becoming an entrepreneur oneself.

In line with Schmitt-Rodermund (2004), our findings imply that entrepreneurial characteristics appear early in life. Schmitt-Rodermund (2004) further suggests that programs that aim to foster entrepreneurship may consider this by introducing activities that develop entrepreneurial characteristics. Type A behavior is a trait-like characteristic and partly genetically inherited (Rebollo and Boomsma 2006), therefore it may not be modified very easily. However, as Schmitt-Rodermund (2004) also suggests, using knowledge about personality characteristics that are known to foster entrepreneurial success may help to develop effective profiling tools for venture capital financing. Among young individuals, the lack of prior work and entrepreneurial experience makes the screening of potentially successful entrepreneurs difficult. Therefore, other tools, such as personality assessments, may be valuable for screening purposes, particularly among young adults. Our findings suggest that personality characteristics measured in adolescence could be used to predict entrepreneurial intentions and success.

\section{Acknowledgements}

The Young Finns Study has been supported by the Academy of Finland (grant numbers 134309 (Eye), 126925, 121584, 124282, 129378 (Salve), 117787 (Gendi), and 41071 (Skidi)); the Social Insurance Institution of Finland; Kuopio, Tampere and Turku University Hospital Medical Funds[grant numbers 9N035 and X51001]; Juho Vainio Foundation; Paavo Nurmi Foundation; Finnish Foundation of Cardiovascular Research; Finnish Cultural Foundation; Tampere Tuberculosis Foundation; Emil Aaltonen Foundation; Laura Pulkki-Råback acknowledges financial support from the Signe and Ane Gyllenberg Foundation and Jutta Viinikainen from the Yrjö Jahnsson foundation (grant number 6664). The use of linked data was supported by Palkansaaja Foundation. 


\section{References}

Andersson, L., \& Hammarstedt, M. (2010). Intergenerational transmissions in immigrant selfemployment: Evidence from three generations. Small Business Economics, 34(3), 261-276.

Babb E. M., \& Babb, S. V. (1992). Psychological traits of rural entrepreneurs. Journal of SocioEconomics, 21(4), 352-362.

Barrick, M. R., Mount, M. K. \& Li, N. (2013). The theory of purposeful behavior: the role of personality, higher-order goals, and job characteristics. Academy of Management Review, 38(1), 132153.

Baumol, W. J. (1990). Entrepreneurship: Productive, unproductive and destructive. Journal of Political Economy, 98(5), 893-921.

Begley, T. M., \& Boyd, D. P. (1987). A Comparison of Entrepreneurs and Managers of Small Business Firms. Journal of Management, 13 (1), 99-108.

Blanchflower, D. J. \& Oswald, A. J. (1998). What makes an entrepreneur? Journal of Labor Economics 16(1), 26-60.

Blumberg, B. F., \& Pfann, G. A. (2015). Roads leading to self-employment: comparing transgenerational entrepreneurs and self-made start-ups. IZA Discussion Paper 9155. Bonn: Institute for the Study of Labor.

Brandstätter, H. (2011). Personality aspect of entrepreneurship: A look at five meta-analyses. Personality and Individual Differences, 51(3), 222-230.

Braunerhjelm, P., Acs, Z. J., Audretsch, D. B., \& Carlsson, B. (2010). The missing link: the knowledge filter and entrepreneurship in endogenous growth. Small Business Economics 34(2), 105125.

Burnam, M. A., Pennebacker, J. W., \& Glass, D. C. (1975). Time consciousness, achievement striving and the Type A coronary-prone behavior pattern. Journal of Abnormal Psychology, 84(1), 76-79.

Böhlmark, A., \& Lindquist, M. (2006). Life-cycle variations in the association between current and lifetime income: Replication and extension for Sweden. Journal of Labor Economics, 24(4), 879-896.

Caliendo, M., Fossen, F., \& Kritikos, A. (2009). Risk Attitudes of Nascent Entrepreneurs - New Evidence from an Experimentally Validated Survey. Small Business Economics, 32(2), 153-167.

Caliendo, M., Fossen, F., \& Kritikos, A. (2010). The Impact of Risk Attitudes on Entrepreneurial Survival. Journal of Economic Behavior and Organization, 76(1), 45-63.

Chlosta, S., Patzelt, H., Klein, S.B., \& Dormann, C. (2012). Parental role models and the decision to become self-employed: The moderating effect of personality. Small Business Economics 38(1), 121138.

Colombier, N., \& Masclet, D. (2008). Intergenerational correlation in self employment: some further evidence from French ECHP data. Small Business Economics, 30(4), 423-437.

Corzine, J. B., \& Hood, J. N. (1998). Shadow and light: Type A behavior and conflict handling styles in entrepreneurs. Journal of Business and Entrepreneurship, 10(2), 115-129. 
De Fruyt, F., \& Mervielde, I. (1997). The five-factor model of personality and Holland's RIASEC interest types. Personality and individual differences, 23(1), 87-103.

Frese, M., \& Gielnik, M. M. (2014). The Psychology of Entrepreneurship. Annual Review of Organizational Psychology \& Organizational Behavior, 1(1), 413-438.

Friedman, M., \& Roseman, R. (1974). Type A Behavior and Your Heart. New York: Knopf.

Haider, S., \& Solon, G. (2006). Life-cycle variation in the association between current and lifetime earnings. American Economic Review, 96(4), 1308-1320.

Hamermesh, D. (2004). Subjective outcomes in economics. Working Papers no. 10361. National Bureau of Economic Research, Cambridge, MA.

Hmieleski, K. M., \& Baron, R. A. (2008). When does entrepreneurial self-effacicy enhance versus reduce firm performance? Strategic Entrepreneurship Journal, 2(1), 57-72.

Holland, J. L. (1985). Making vocational choices. A theory on vocational personalities and work environments. Englewood Cliffs, NJ: Prentice-Hall.

Holmes T. J., \& Schmitz, J. A. Jr (1990). A theory of entrepreneurship and its applications to the study of business transfers. Journal of Political Economy, 98(2), 265-294.

Jamal, M. (1985). Type A behavior and job performance: Some suggestive findings. Journal of Human Stress, 11(2), 60-68.

Jamal, M., \& Baba, V. V. (2001). Type-A behavior, job performance, and well-being in college teachers. International Journal of Stress Management, 8(3), 231-240.

Jokela, M., \& Keltikangas-Järvinen, L. (2009). Adolescent Leadership and Adulthood Fertility: Revisiting the "Central Theoretical Problem of Human Sociobiology". Journal of Personality, 77(1), 213-229.

Lazear, E. P. (2004). Balanced skills and entrepreneurship. American Economic Review, Papers and Proceedings, 94(2), 208-211.

Lee, C., Earley, P. C., \& Hanson, L. A. (1988). Are Type As better performers? Journal of Organizational Behavior, 9(3), 263-269.

Lindquist, M. J., Sol, J., \& Van Praag, M. (2015). Why do entrepreneurial parents have entrepreneurial children?. Journal of Labor Economics, 33(2), 269-296.

Matteson, M. T., Ivancevich, J. M., \& Smith, S. V. (1984). Relation of Type A behavior to performance and satisfaction among sales personnel. Journal of Vocational Behavior, 25(2), 203-214.

Matthews, K. A., Helmreich, R. L., Beane, W. E., \& Lucker, G. W. (1980). Pattern A, achievementstriving, and scientific merit: does pattern A help or hinder? Journal of Personality and Social Psychology, 39(5), 962-967.

Morrison, K. A. (1997). How franchise job satisfaction and personality affects performance, organizational commitment, franchisor relations, and intention to remain. Journal of Small Business Management, 35(3), 39-67. 
Mueller, G., \& Plug, E. (2006). Estimating the effect of personality on male and female earnings. Industrial \& Labor Relations Review, 60(1), 3-22.

Rauch, A., \& Frese, M. (2007). Let's put the person back into entrepreneurship research: a metaanalysis on the relationship between business owners' personality traits, business creation, and success. European journal of work and organizational psychology, 16(4), 353-385.

Rebollo, I., \& Boomsma, D. I. (2006). Genetic and environmental influences on type A behavior pattern: evidence from twins and their parents in the Netherlands Twin Register. Psychosomatic medicine, 68(3), 437-442.

Santarelli, E., \& Vivarelli, M. (2007). Entrepreneurship and the process of firms' entry, survival and growth. Industrial and Corporate Change, 16(3), 455-488.

Schmitt-Rodermund, E. (2004). Pathways to successful entrepreneurship: Parenting, personality, early entrepreneurial competence, and interests. Journal of Vocational Behavior, 65(3), 498-518.

Schumpeter, J. A. (1934). The theory of economic development. Cambridge, Massachusetts: Harvard University Press.

Sørensen, J. B. (2007). Closure and exposure: Mechanisms in the intergenerational transmission of self-employment. Research in the Sociology of Organizations, 25(83), 124.

Taylor, M. S., Locke, E. A., Lee, C., \& Gist, M. (1984). Type A behavior and faculty research productivity: what are the mechanisms? Organizational Behavior and Human Performance, 34(3), 402-418.

Vecchio, R. P. (2003). Entrepreneurship and leadership: common trends and common threats. Human Resource Management Review, 13(2), 303-327.

Wolf, T. M., Sklov, M. C., Wenzl P. A., Hunter, S. M., \& Berenson G. S. (1982). Validation of a Measure of Type A Behavior Pattern in Children: Bogalusa Heart Study. Child Development, 53(1), 136-135.

Yrittäjyyskatsaus 2012 (2012). Ministry of Employment and the Economy 46/2012. https://www.tem.fi/files/35080/TEMjul_46_2012_web.pdf (in Finnish).

Zhao, H., \& Seibert, S. E. (2006). The Big Five Personality Dimensions and Entrepreneurial Status: A meta-analytic review. Journal of Applied Psychology, 91(2), 259-271. 
Table 1 Descriptive statistics

\begin{tabular}{|c|c|c|c|}
\hline & $\begin{array}{c}\text { (1) } \\
\text { Females + Males } \\
\end{array}$ & $\begin{array}{c}(2) \\
\text { Females }\end{array}$ & $\begin{array}{c}(3) \\
\text { Males }\end{array}$ \\
\hline \multicolumn{4}{|l|}{ Entrepreneurship measures (1990-2010) } \\
\hline Ever self-employed & $\begin{array}{c}0.179 \\
(0.384) \\
\end{array}$ & $\begin{array}{c}0.145 \\
(0.352) \\
\end{array}$ & $\begin{array}{c}0.219 \\
(0.414) \\
\end{array}$ \\
\hline Share of self-employment years & $\begin{array}{c}0.069 \\
(0.196) \\
\end{array}$ & $\begin{array}{c}0.050 \\
(0.164)\end{array}$ & $\begin{array}{c}0.090 \\
(0.225)\end{array}$ \\
\hline $\begin{array}{l}\text { At least } 5 \text { subsequent years of self- } \\
\text { employment }\end{array}$ & $\begin{array}{c}0.061 \\
(0.240)\end{array}$ & $\begin{array}{c}0.054 \\
(0.225)\end{array}$ & $\begin{array}{c}0.083 \\
(0.277)\end{array}$ \\
\hline $\begin{array}{l}\text { Average duration of self-employment spell in } \\
\text { years; self-employed only }(\mathrm{N}=355)\end{array}$ & $\begin{array}{c}6.847 \\
(6.144)\end{array}$ & $\begin{array}{c}6.136 \\
(5.869)\end{array}$ & $\begin{array}{c}7.386 \\
(6.307)\end{array}$ \\
\hline $\begin{array}{l}\text { Number of self-employment spells; self- } \\
\text { employed only }(\mathrm{N}=355)\end{array}$ & $\begin{array}{c}1.270 \\
(0.552) \\
\end{array}$ & $\begin{array}{c}1.288 \\
(0.558) \\
\end{array}$ & $\begin{array}{c}1.257 \\
(0.549)\end{array}$ \\
\hline $\begin{array}{l}\text { Average annual sales (in year } 2000 \text { Euros); } \\
\text { self-employed only }(\mathrm{N}=136)\end{array}$ & $\begin{array}{c}345781.10 \\
(992626.90)\end{array}$ & $\begin{array}{l}343270.30 \\
(1053685)\end{array}$ & $\begin{array}{c}347335.40 \\
(959375)\end{array}$ \\
\hline \multicolumn{4}{|l|}{ Type A behavior traits (1986) } \\
\hline Aggression & $\begin{array}{c}3.674 \\
(0.865) \\
\end{array}$ & $\begin{array}{c}3.757 \\
(0.891) \\
\end{array}$ & $\begin{array}{c}3.579 \\
(0.824) \\
\end{array}$ \\
\hline Leadership & $\begin{array}{c}4.164 \\
(0.839)\end{array}$ & $\begin{array}{c}4.079 \\
(0.838)\end{array}$ & $\begin{array}{c}4.262 \\
(0.830)\end{array}$ \\
\hline Responsibility & $\begin{array}{c}4.862 \\
(1.025)\end{array}$ & $\begin{array}{c}5.007 \\
(1.013)\end{array}$ & $\begin{array}{c}4.696 \\
(1.015)\end{array}$ \\
\hline Eagerness-Energy & $\begin{array}{c}4.699 \\
(0.681)\end{array}$ & $\begin{array}{c}4.722 \\
(0.693)\end{array}$ & $\begin{array}{c}4.672 \\
(0.665)\end{array}$ \\
\hline \multicolumn{4}{|l|}{ Socio-demographic characteristics } \\
\hline Gender (Female $=1)$ & $\begin{array}{c}0.534 \\
(0.499)\end{array}$ & - & - \\
\hline Higher education (2010) & $\begin{array}{c}0.289 \\
(0.454)\end{array}$ & $\begin{array}{c}0.309 \\
(0.462)\end{array}$ & $\begin{array}{c}0.266 \\
(0.442)\end{array}$ \\
\hline Share of marital years (1990-2010) & $\begin{array}{c}0.402 \\
(0.359) \\
\end{array}$ & $\begin{array}{c}0.433 \\
(0.363) \\
\end{array}$ & $\begin{array}{c}0.366 \\
(0.351) \\
\end{array}$ \\
\hline $\begin{array}{l}\text { Family background } \\
\text { - Entrepreneurs in the family (1980) }\end{array}$ & $\begin{array}{c}0.394 \\
(0.489) \\
\end{array}$ & $\begin{array}{c}0.389 \\
(0.488) \\
\end{array}$ & $\begin{array}{c}0.399 \\
(0.490) \\
\end{array}$ \\
\hline \multicolumn{4}{|l|}{ Cohort } \\
\hline - Cohort born in 1974 & $\begin{array}{c}0.236 \\
(0.425)\end{array}$ & $\begin{array}{c}0.229 \\
(0.420)\end{array}$ & $\begin{array}{c}0.244 \\
(0.429)\end{array}$ \\
\hline - $\quad$ Cohort born in 1971 & $\begin{array}{c}0.241 \\
(0.428)\end{array}$ & $\begin{array}{c}0.227 \\
(0.419)\end{array}$ & $\begin{array}{c}0.258 \\
(0.438)\end{array}$ \\
\hline - $\quad$ Cohort born in 1968 & $\begin{array}{c}0.206 \\
(0.405)\end{array}$ & $\begin{array}{c}0.216 \\
(0.412)\end{array}$ & $\begin{array}{c}0.195 \\
(0.396)\end{array}$ \\
\hline - $\quad$ Cohort born in 1965 & $\begin{array}{c}0.166 \\
(0.372)\end{array}$ & $\begin{array}{c}0.167 \\
(0.374)\end{array}$ & $\begin{array}{c}0.165 \\
(0.371)\end{array}$ \\
\hline - $\quad$ Cohort born in 1962 & $\begin{array}{c}0.151 \\
(0.358)\end{array}$ & $\begin{array}{c}0.161 \\
(0.368)\end{array}$ & $\begin{array}{c}0.140 \\
(0.347)\end{array}$ \\
\hline \multicolumn{4}{|l|}{ Region (1986) } \\
\hline - Helsinki & $\begin{array}{c}0.169 \\
(0.374)\end{array}$ & $\begin{array}{c}0.175 \\
(0.380)\end{array}$ & $\begin{array}{c}0.161 \\
(0.368)\end{array}$ \\
\hline - $\quad$ Turku & $\begin{array}{c}0.182 \\
(0.386)\end{array}$ & $\begin{array}{c}0.166 \\
(0.372)\end{array}$ & $\begin{array}{c}0.201 \\
(0.401)\end{array}$ \\
\hline - $\quad$ Tampere & $\begin{array}{c}0.187 \\
(0.390)\end{array}$ & $\begin{array}{c}0.190 \\
(0.392)\end{array}$ & $\begin{array}{c}0.184 \\
(0.388)\end{array}$ \\
\hline - Kuopio & $\begin{array}{c}0.307 \\
(0.461)\end{array}$ & $\begin{array}{c}0.311 \\
(0.463)\end{array}$ & $\begin{array}{c}0.302 \\
(0.459)\end{array}$ \\
\hline - Oulu & $\begin{array}{c}0.155 \\
(0.362)\end{array}$ & $\begin{array}{c}0.158 \\
(0.365)\end{array}$ & $\begin{array}{c}0.152 \\
(0.359)\end{array}$ \\
\hline $\mathrm{N}$ & 1981 & 1057 & 924 \\
\hline
\end{tabular}

Source: YFS-FLEED-LPC, 1990-2010. 
Table 2 Descriptive statistics by self-employment status

\begin{tabular}{|c|c|c|c|c|}
\hline & $\begin{array}{c}(1) \\
\text { Never self- } \\
\text { employed (1990- } \\
2010)\end{array}$ & $\begin{array}{c}(2) \\
\text { Self-employed } \\
(1990-2010) \\
\text { (at least once) }\end{array}$ & $\begin{array}{c}(3) \\
\text { Difference }\end{array}$ & $\begin{array}{c}\text { (4) } \\
\text { t-statistics }\end{array}$ \\
\hline \multicolumn{5}{|l|}{ Personality measures (1986) } \\
\hline Aggression & $\begin{array}{c}3.682 \\
(0.874)\end{array}$ & $\begin{array}{c}3.640 \\
(0.819)\end{array}$ & 0.042 & 0.824 \\
\hline Leadership & $\begin{array}{c}4.129 \\
(0.021)\end{array}$ & $\begin{array}{c}4.325 \\
(0.044) \\
\end{array}$ & -0.196 & $-3.992 * * *$ \\
\hline Responsibility & $\begin{array}{c}4.859 \\
(1.025)\end{array}$ & $\begin{array}{c}4.878 \\
(1.031)\end{array}$ & -0.019 & -0.321 \\
\hline Eagerness-Energy & $\begin{array}{c}4.689 \\
(0.687) \\
\end{array}$ & $\begin{array}{r}4.744 \\
(0.651) \\
\end{array}$ & -0.055 & -1.375 \\
\hline \multicolumn{5}{|l|}{ Socio-demographic characteristics } \\
\hline Gender $($ Female $=1)$ & $\begin{array}{c}0.556 \\
(0.497)\end{array}$ & $\begin{array}{c}0.431 \\
(0.496)\end{array}$ & 0.125 & $4.294 * * *$ \\
\hline Higher education (2010) & $\begin{array}{r}0.314 \\
(0.464) \\
\end{array}$ & $\begin{array}{c}0.177 \\
(0.383) \\
\end{array}$ & 0.136 & $5.835 * * *$ \\
\hline Share of marital years (1990-2010) & $\begin{array}{c}0.387 \\
(0.357)\end{array}$ & $\begin{array}{c}0.474 \\
(0.360)\end{array}$ & -0.088 & $-4.190 * * *$ \\
\hline $\begin{array}{l}\text { Family background } \\
\text { - Entrepreneurs in the family } \\
(1980)\end{array}$ & $\begin{array}{c}0.366 \\
(0.482)\end{array}$ & $\begin{array}{c}0.521 \\
(0.500)\end{array}$ & -0.155 & $-5.460 * * *$ \\
\hline $\begin{array}{c}\text { Cohorts (row percentages) } \\
-\quad \text { Cohort born in } 1974\end{array}$ & 0.8501 & 0.1499 & & \\
\hline - $\quad$ Cohort born in 1971 & 0.8326 & 0.1674 & & \\
\hline - $\quad$ Cohort born in 1968 & 0.8235 & 0.1765 & & \\
\hline - Cohort born in 1965 & 0.8024 & 0.1976 & & \\
\hline - $\quad$ Cohort born in 1962 & 0.7726 & 0.2274 & & \\
\hline $\begin{array}{l}\text { Region (1986) (row percentages) } \\
-\quad \text { Helsinki }\end{array}$ & 0.8383 & 0.1617 & & \\
\hline - $\quad$ Turku & 0.7729 & 0.2271 & & \\
\hline - Tampere & 0.8383 & 0.1617 & & \\
\hline - Kuopio & 0.8207 & 0.1793 & & \\
\hline - Oulu & 0.8371 & 0.1629 & & \\
\hline $\mathrm{N}$ & 1626 & 355 & & \\
\hline
\end{tabular}


Table 3 Correlations between Type A personality and entrepreneurial success measures (entrepreneurs only, $\mathrm{N}=$ 355/136)

\begin{tabular}{|l|c|c|c|c|}
\hline & Aggression & Leadership & Responsibility & $\begin{array}{l}\text { Eagerness- } \\
\text { Energy }\end{array}$ \\
\hline $\begin{array}{l}\text { Average duration of self- } \\
\text { employment spells ( } \mathrm{N}=355)\end{array}$ & -0.062 & -0.037 & $0.113^{* *}$ & 0.066 \\
\hline $\begin{array}{l}\text { Number of self-employment spells } \\
(\mathrm{N}=355)\end{array}$ & 0.000 & $0.097^{*}$ & $0.108^{* *}$ & -0.024 \\
\hline Average annual sales ( $=136)$ & -0.004 & $0.232^{* * *}$ & -0.053 & 0.135 \\
\hline
\end{tabular}


Table 4 Type A personality traits and entrepreneurship; OLS estimation

\begin{tabular}{|c|c|c|c|}
\hline & $\begin{array}{c}\text { (1) } \\
\text { Ever self-employed }\end{array}$ & $\begin{array}{c}(2) \\
\text { Share of self- } \\
\text { employment years }\end{array}$ & $\begin{array}{c}\text { (3) } \\
\text { At least } 5 \\
\text { subsequent years of } \\
\text { self-employment }\end{array}$ \\
\hline Aggression & $\begin{array}{l}-0.003 \\
(0.008)\end{array}$ & $\begin{array}{c}0.000 \\
(0.004)\end{array}$ & $\begin{array}{c}0.002 \\
(0.006)\end{array}$ \\
\hline Leadership & $\begin{array}{c}0.040 * * * \\
(0.008)\end{array}$ & $\begin{array}{c}0.016^{* * *} \\
(0.004)\end{array}$ & $\begin{array}{c}0.026 * * * \\
(0.006)\end{array}$ \\
\hline Responsibility & $\begin{array}{l}-0.007 \\
(0.009) \\
\end{array}$ & $\begin{array}{c}0.002 \\
(0.004) \\
\end{array}$ & $\begin{array}{c}0.000 \\
(0.007) \\
\end{array}$ \\
\hline Eagerness-Energy & $\begin{array}{c}0.003 \\
(0.008)\end{array}$ & $\begin{array}{c}0.000 \\
(0.004)\end{array}$ & $\begin{array}{l}-0.003 \\
(0.006)\end{array}$ \\
\hline Female & $\begin{array}{c}-0.048 * * * \\
(0.016)\end{array}$ & $\begin{array}{c}-0.026^{* * *} \\
(0.007)\end{array}$ & $\begin{array}{c}-0.040 * * * \\
(0.012)\end{array}$ \\
\hline University education & $\begin{array}{c}-0.091 * * * \\
(0.017) \\
\end{array}$ & $\begin{array}{c}-0.048^{* * *} \\
(0.007) \\
\end{array}$ & $\begin{array}{c}-0.066 * * * \\
(0.012)\end{array}$ \\
\hline $\begin{array}{l}\text { Family background: mother or } \\
\text { father with self-employment } \\
\text { experience }\end{array}$ & $\begin{array}{l}0.045^{* * *} \\
(0.017)\end{array}$ & $\begin{array}{c}0.016 * * \\
(0.008)\end{array}$ & $\begin{array}{c}0.026 * * \\
(0.013)\end{array}$ \\
\hline Agricultural sector & $\begin{array}{c}0.796 * * * \\
(0.018)\end{array}$ & $\begin{array}{c}0.579 * * * \\
(0.037)\end{array}$ & $\begin{array}{c}0.795^{* * *} \\
(0.038)\end{array}$ \\
\hline $\begin{array}{l}\text { Share of marital years (1990- } \\
\text { 2010) }\end{array}$ & $\begin{array}{c}0.068 * * * \\
(0.024)\end{array}$ & $\begin{array}{l}0.024 * * \\
(0.012)\end{array}$ & $\begin{array}{l}0.034^{*} \\
(0.019)\end{array}$ \\
\hline \multicolumn{4}{|l|}{$\begin{array}{l}\text { Cohorts (reference group: } \\
\text { cohort born in 1974) }\end{array}$} \\
\hline - $\quad$ Cohort born in 1971 & $\begin{array}{l}-0.009 \\
(0.022)\end{array}$ & $\begin{array}{l}-0.003 \\
(0.008)\end{array}$ & $\begin{array}{r}-0.002 \\
(0.016) \\
\end{array}$ \\
\hline - $\quad$ Cohort born in 1968 & $\begin{array}{c}0.007 \\
(0.025)\end{array}$ & $\begin{array}{c}0.012 \\
(0.010)\end{array}$ & $\begin{array}{c}0.006 \\
(0.018)\end{array}$ \\
\hline - $\quad$ Cohort born in 1965 & $\begin{array}{l}-0.013 \\
(0.026)\end{array}$ & $\begin{array}{c}0.027 * * \\
(0.012)\end{array}$ & $\begin{array}{l}0.037 * \\
(0.021)\end{array}$ \\
\hline - $\quad$ Cohort born in 1962 & $\begin{array}{c}0.015 \\
(0.029)\end{array}$ & $\begin{array}{c}0.047 * * * \\
(0.014)\end{array}$ & $\begin{array}{l}0.043^{*} \\
(0.023)\end{array}$ \\
\hline \multicolumn{4}{|l|}{$\begin{array}{l}\text { Region (reference group: } \\
\text { Helsinki) }\end{array}$} \\
\hline - $\quad$ Turku & $\begin{array}{l}-0.001 \\
(0.027)\end{array}$ & $\begin{array}{c}0.007 \\
(0.012) \\
\end{array}$ & $\begin{array}{c}0.005 \\
(0.020) \\
\end{array}$ \\
\hline - Tampere & $\begin{array}{l}-0.004 \\
(0.027)\end{array}$ & $\begin{array}{c}0.005 \\
(0.012) \\
\end{array}$ & $\begin{array}{c}0.002 \\
(0.020) \\
\end{array}$ \\
\hline - Kuopio & $\begin{array}{l}-0.002 \\
(0.024)\end{array}$ & $\begin{array}{c}0.009 \\
(0.010)\end{array}$ & $\begin{array}{c}0.006 \\
(0.018)\end{array}$ \\
\hline - Oulu & $\begin{array}{l}-0.009 \\
(0.027)\end{array}$ & $\begin{array}{c}0.003 \\
(0.012)\end{array}$ & $\begin{array}{c}-0.010 \\
(0.020)\end{array}$ \\
\hline $\mathrm{R}^{2}$ & 0.1740 & 0.3182 & 0.2488 \\
\hline $\mathrm{N}$ & 1981 & 1981 & 1981 \\
\hline
\end{tabular}


Table 5 Type A personality traits and entrepreneurship; IV estimation

\begin{tabular}{|c|c|c|c|}
\hline & $\begin{array}{c}(1) \\
\text { Ever self-employed }\end{array}$ & $\begin{array}{c}\text { (2) } \\
\text { Share of self- } \\
\text { employment years }\end{array}$ & $\begin{array}{c}\text { (3) } \\
\text { At least } 5 \\
\text { subsequent years of } \\
\text { self-employment }\end{array}$ \\
\hline Aggression & $\begin{array}{c}0.016 \\
(0.020)\end{array}$ & $\begin{array}{l}0.020^{*} \\
(0.011)\end{array}$ & $\begin{array}{c}0.020 \\
(0.016)\end{array}$ \\
\hline Leadership & $\begin{array}{c}0.075^{* * *} \\
(0.019)\end{array}$ & $\begin{array}{c}0.035^{* * *} \\
(0.011)\end{array}$ & $\begin{array}{l}0.039 * * \\
(0.016)\end{array}$ \\
\hline Responsibility & $\begin{array}{c}-0.022 \\
(0.024)\end{array}$ & $\begin{array}{c}0.005 \\
(0.012)\end{array}$ & $\begin{array}{c}0.006 \\
(0.019)\end{array}$ \\
\hline Eagerness-Energy & $\begin{array}{l}-0.050 \\
(0.030)\end{array}$ & $\begin{array}{l}-0.029 * \\
(0.016)\end{array}$ & $\begin{array}{l}-0.029 \\
(0.024)\end{array}$ \\
\hline Female & $\begin{array}{l}-0.030 \\
(0.023) \\
\end{array}$ & $\begin{array}{c}-0.030 * * \\
(0.012)\end{array}$ & $\begin{array}{c}-0.045^{* *} \\
(0.018)\end{array}$ \\
\hline University education & $\begin{array}{l}-0.094 \\
(0.024)\end{array}$ & $\begin{array}{c}-0.062 * * * \\
(0.010)\end{array}$ & $\begin{array}{c}-0.081^{* * * *} \\
(0.017)\end{array}$ \\
\hline $\begin{array}{l}\text { Family background: mother or } \\
\text { father with self-employment } \\
\text { experience }\end{array}$ & $\begin{array}{c}0.062 * * * \\
(0.022)\end{array}$ & $\begin{array}{l}0.021 * \\
(0.011)\end{array}$ & $\begin{array}{l}0.029 * \\
(0.017)\end{array}$ \\
\hline Agricultural sector & $\begin{array}{c}0.785^{* * *} \\
(0.027)\end{array}$ & $\begin{array}{l}0.600 * * * \\
(0.042)\end{array}$ & $\begin{array}{c}0.823 * * * \\
(0.038)\end{array}$ \\
\hline $\begin{array}{l}\text { Share of marital years (1990- } \\
\text { 2010) }\end{array}$ & $\begin{array}{c}0.076^{* * *} \\
(0.029)\end{array}$ & $\begin{array}{l}0.029 * \\
(0.015)\end{array}$ & $\begin{array}{l}0.042 * \\
(0.023)\end{array}$ \\
\hline \multicolumn{4}{|l|}{$\begin{array}{l}\text { Cohorts (reference group: } \\
\text { cohort born in 1971) }\end{array}$} \\
\hline - $\quad$ Cohort born in 1968 & $\begin{array}{c}0.016 \\
(0.026)\end{array}$ & $\begin{array}{l}0.021 * \\
(0.012)\end{array}$ & $\begin{array}{c}0.013 \\
(0.019)\end{array}$ \\
\hline - $\quad$ Cohort born in 1965 & $\begin{array}{c}0.019 \\
(0.030) \\
\end{array}$ & $\begin{array}{c}0.038 * * \\
(0.016) \\
\end{array}$ & $\begin{array}{l}0.043^{*} \\
(0.025) \\
\end{array}$ \\
\hline - $\quad$ Cohort born in 1962 & $\begin{array}{c}0.070 \\
(0.036) \\
\end{array}$ & $\begin{array}{c}0.074 * * * \\
(0.020)\end{array}$ & $\begin{array}{c}0.065 * * \\
(0.029) \\
\end{array}$ \\
\hline \multicolumn{4}{|l|}{$\begin{array}{l}\text { Region (reference group: } \\
\text { Helsinki) }\end{array}$} \\
\hline - $\quad$ Turku & $\begin{array}{c}0.007 \\
(0.034) \\
\end{array}$ & $\begin{array}{c}0.009 \\
(0.016)\end{array}$ & $\begin{array}{l}-0.017 \\
(0.026) \\
\end{array}$ \\
\hline - $\quad$ Tampere & $\begin{array}{l}-0.004 \\
(0.033) \\
\end{array}$ & $\begin{array}{c}0.007 \\
(0.016) \\
\end{array}$ & $\begin{array}{l}-0.015 \\
(0.027) \\
\end{array}$ \\
\hline - $\quad$ Kuopio & $\begin{array}{c}0.004 \\
(0.031) \\
\end{array}$ & $\begin{array}{c}0.013 \\
(0.015) \\
\end{array}$ & $\begin{array}{l}-0.006 \\
(0.025) \\
\end{array}$ \\
\hline - $\quad$ Oulu & $\begin{array}{l}-0.002 \\
(0.035)\end{array}$ & $\begin{array}{l}-0.004 \\
(0.017) \\
\end{array}$ & $\begin{array}{c}-0.035 \\
(0.027) \\
\end{array}$ \\
\hline $\mathrm{N}$ & 1249 & 1249 & 1249 \\
\hline
\end{tabular}

obtained in 1986. The instruments are Type A characteristics, obtained in 1983. The first-stage F-statistics on the excluded instruments were 162.14 for Aggression, 185.83 for Leadership, 65.72 for Responsibility, and 63.89 for Eagerness-Energy.

Source: YFS-FLEED-LPC, 1990-2010. 
Table 6 Entrepreneurial success (entrepreneurs only); OLS estimation

\begin{tabular}{|c|c|c|c|}
\hline & $\begin{array}{c}\text { (1) } \\
\text { Average duration } \\
\text { of self- } \\
\text { employment } \\
\text { spell } \\
\end{array}$ & $\begin{array}{c}(2) \\
\text { Number of self- } \\
\text { employment } \\
\text { spells } \\
\text { 1990-2010 }\end{array}$ & $\begin{array}{c}(3) \\
\ln (\text { Sales })\end{array}$ \\
\hline Aggression & $\begin{array}{c}0.065 \\
(0.319) \\
\end{array}$ & $\begin{array}{c}0.010 \\
(0.032)\end{array}$ & $\begin{array}{c}0.057 \\
(0.139)\end{array}$ \\
\hline Leadership & $\begin{array}{l}-0.102 \\
(0.331)\end{array}$ & $\begin{array}{l}0.084 * * \\
(0.041)\end{array}$ & $\begin{array}{l}0.286 * * \\
(0.127)\end{array}$ \\
\hline Responsibility & $\begin{array}{c}0.041 \\
(0.287)\end{array}$ & $\begin{array}{l}0.064 * * \\
(0.026)\end{array}$ & $\begin{array}{l}-0.169 \\
(0.143)\end{array}$ \\
\hline Eagerness-Energy & $\begin{array}{c}0.190 \\
(0.351)\end{array}$ & $\begin{array}{l}-0.048 \\
(0.038)\end{array}$ & $\begin{array}{c}0.031 \\
(0.126)\end{array}$ \\
\hline Female & $\begin{array}{l}-0.909 \\
(0.570)\end{array}$ & $\begin{array}{c}0.022 \\
(0.057)\end{array}$ & $\begin{array}{l}-0.375 \\
(0.312)\end{array}$ \\
\hline University education & $\begin{array}{c}-2.306^{* * *} \\
(0.611)\end{array}$ & $\begin{array}{l}-0.051 \\
(0.079)\end{array}$ & $\begin{array}{c}0.407 \\
(0.370)\end{array}$ \\
\hline $\begin{array}{l}\text { Family background: self- } \\
\text { employed in the family }\end{array}$ & $\begin{array}{l}-0.020 \\
(0.613) \\
\end{array}$ & $\begin{array}{c}0.003 \\
(0.058) \\
\end{array}$ & $\begin{array}{l}-0.116 \\
(0.257)\end{array}$ \\
\hline Agricultural sector & $\begin{array}{l}5.415^{* * *} \\
(0.926)\end{array}$ & $\begin{array}{c}0.085 \\
(0.088) \\
\end{array}$ & $\begin{array}{l}-0.351 \\
(0.825)\end{array}$ \\
\hline Share of marital years & $\begin{array}{c}0.428 \\
(0.932)\end{array}$ & $\begin{array}{l}-0.014 \\
(0.093)\end{array}$ & $\begin{array}{l}0.816^{* *} \\
(0.313)\end{array}$ \\
\hline \multicolumn{4}{|l|}{$\begin{array}{l}\text { Cohorts (reference group: } \\
\text { cohort born in 1974) }\end{array}$} \\
\hline $\begin{array}{ll}- & \text { Cohort born in } \\
1971\end{array}$ & $\begin{array}{c}0.367 \\
(0.626)\end{array}$ & $\begin{array}{l}-0.043 \\
(0.098)\end{array}$ & $\begin{array}{c}0.545 \\
(0.375) \\
\end{array}$ \\
\hline $\begin{array}{ll}- & \text { Cohort born in } \\
1968\end{array}$ & $\begin{array}{l}2.029 * * \\
(0.826)\end{array}$ & $\begin{array}{l}-0.159 * \\
(0.096)\end{array}$ & $\begin{array}{c}0.231 \\
(0.357) \\
\end{array}$ \\
\hline $\begin{array}{ll}- & \text { Cohort born in } \\
1965\end{array}$ & $\begin{array}{c}3.675^{* * *} \\
(0.903) \\
\end{array}$ & $\begin{array}{l}-0.099 \\
(0.105)\end{array}$ & $\begin{array}{l}0.585^{*} \\
(0.324)\end{array}$ \\
\hline $\begin{array}{ll}-\quad & \text { Cohort born in } \\
& 1962\end{array}$ & $\begin{array}{l}4.406^{* * *} \\
(0.967)\end{array}$ & $\begin{array}{l}-0.084 \\
(0.107)\end{array}$ & $\begin{array}{c}0.101 \\
(0.327)\end{array}$ \\
\hline \multicolumn{4}{|l|}{$\begin{array}{l}\text { Region (reference group: } \\
\text { Helsinki) }\end{array}$} \\
\hline - $\quad$ Turku & $\begin{array}{c}0.812 \\
(0.932)\end{array}$ & $\begin{array}{l}-0.041 \\
(0.100)\end{array}$ & $\begin{array}{c}0.479 \\
(0.419)\end{array}$ \\
\hline - $\quad$ Tampere & $\begin{array}{c}0.654 \\
(0.956)\end{array}$ & $\begin{array}{c}0.014 \\
(0.113)\end{array}$ & $\begin{array}{c}0.203 \\
(0.369)\end{array}$ \\
\hline - Kuopio & $\begin{array}{r}0.894 \\
(0.841) \\
\end{array}$ & $\begin{array}{l}-0.047 \\
(0.092)\end{array}$ & $\begin{array}{c}0.355 \\
(0.302) \\
\end{array}$ \\
\hline - $\quad$ Oulu & $\begin{array}{c}-0.469 \\
(1.087) \\
\end{array}$ & $\begin{array}{l}0.222 * \\
(0.123)\end{array}$ & $\begin{array}{c}0.269 \\
(0.410)\end{array}$ \\
\hline $\mathrm{R}^{2}$ & 0.2723 & 0.0593 & 0.190 \\
\hline $\mathrm{N}$ & 355 & 355 & 136 \\
\hline
\end{tabular}

in 1986.

Source: YFS-FLEED-LPC, 1990-2010. 